\title{
Quality in the Attention of Patients with the Human Immunodeficiency Virus (Hiv): Actions Carried Out by Colombia and Mexico
}

\author{
Calidad en la atención en pacientes con el virus de Inmunodeficiencia Humana: Acciones \\ realizadas por Colombia y México
}

Kenny P. Ramírez-Camargo ${ }^{a}$

Received: 01/09/2018, Accepted: 30/11/2018, Published: 05/01/2019

\begin{abstract}
:
The quality of care for people diagnosed with Human Immunodeficiency Virus (HIV) and the Acquired Immunodeficiency Syndrome $(A I D S)$ has been managed for years with a reductionist vision regarding what the user requires. In terms of health care, there is a good or bad attention regarding the diagnosis, ignorance, stigma associated with it, the system, low training of the health provider, etc. This article aims at reviewing from a literature perspective the different actions that Colombia and Mexico have carried out in relation to the health care of these users and if there are advances over the years or if the same practices that generate low quality care to these users are still adopted.
\end{abstract}

\section{Keywords:}

Quality of care; Human Immunodeficiency Virus (HIV) and the Acquired Immunodeficiency Syndrome (AIDS); Colombia; Mexico

\section{Resumen:}

La calidad en la atención para las personas diagnosticadas por el Virus de Inmunodeficiencia Humana (VIH) o el síndrome de inmunodeficiencia adquirida (SIDA) se ha manejado desde hace años con una visión reduccionista con respecto a lo que el usuario requiere frente a la atención en salud, se da una buena o mala atención dado por su diagnóstico, el desconocimiento, estigma asociado al mismo, el sistema, baja capacitación del prestador de salud. En este artículo se pretende revisar desde la literatura las diferentes acciones que han realizado Colombia y México frente a la atención en salud de estos usuarios y si hay avances a través de los años o se sigue con las mismas prácticas que generan baja calidad en la atención de estos usuarios.

\section{Palabras Clave:}

Calidad en la atención; Virus de Inmunodeficiencia Humana (VIH); síndrome de inmunodeficiencia adquirida (SIDA); Colombia; México

\section{INTRODUCTION}

Human Immunodeficiency Virus (HIV) infection and the Acquired Immunodeficiency Syndrome (AIDS) affects around 34 million people worldwide, of which 23.5 million are in Sub-Saharan Africa and the remaining 10.5 million are distributed in Oceania with 53,000 people, 300,000 in the Middle East and North Africa, while in Europe there are 2.3 million, in the Americas region 2.8 million and Asia with 4.8 million. ${ }^{1,2}$
AIDS is an advanced stage of HIV infection, which attacks the body's defenses and alters its ability to fight against diseases caused by other viruses, bacteria, parasites and fungi. Every day there are about 14,000 new infected people; of which more than $95 \%$ are reported in developing nations, of which $80 \%$ are infected by heterosexual relationships, about 12,000 are from the age group between 15 and 49 years old and $50 \%$ are women between 15 and 24 years old. ${ }^{3}$

${ }^{a}$ Corresponding author: Escuela de Medicina y Ciencias de la Salud, Programa de Fisioterapia, Universidad del Rosario. Carrera $24 \mathrm{~N}^{\circ} 63 \mathrm{C}-$ 69. Bogotá, Colombia. Tel: +57 031 4225321, E-mail: newyork.kenny@gmail.com 
After almost four decades since the appearance of the first cases of HIV/AIDS in the world, significant advances in detection, treatment and prevention have been observed as a result of the joint work of various government agencies and organized civil society to treat this global problem. ${ }^{4}$ But at the same time, HIV/AIDS is considered a chronic disease and requires the participation of different professionals and the correct follow-up, control and health care quality, that will depend, to a large extent, on the patient's prognosis. ${ }^{5}$

Currently, this epidemic is a public health problem, so there is a consensus between researchers and health managers; since there is no cure, it is vitally important to work on prevention. This has generated a number of strategies directed by health managers towards the universalization of antiretroviral treatment in order to improve the quality of life and the survival of people living with HIV. ${ }^{4}$

\section{BACKGROUND ON HIV/AIDS IN COLOMBIA AND MEXICO}

In Colombia, there are prevalences higher than $5 \%$ in vulnerable populations such as: Men who have sex with other men (MSM), transgender women, and people living in the street; classifying the country in a concentrated epidemic while the general population has a prevalence of less than $1 \% .^{6}$ Due to the need of adopting and implementing comprehensive care guidelines for health promotion, prevention, treatment and control of diseases, according to the resolution 412 of 2000 , the Ministry of Health of Colombia defines a group of early detection interventions, specific protection and care of diseases of the public health interest through technical standards and care guidelines. ${ }^{7}$ However, despite the existence of policies and guidelines proposed by the ministry, HIV and AIDS continue to be a national problem, $11 \%$ of people living with HIV do not have health insurance and there is no data available on $55 \%$ of the affected population. ${ }^{8}$ The access barriers to the health system are greater for women in poverty and have insufficient access to health insurance, they invest more of their own resources as a financial source and they are exposed to low-quality care through subsidies. ${ }^{8}$

In Mexico the AIDS epidemic is predominantly sexual.This type of transmission has been the cause of almost $90 \%$ of the accumulated cases of this disease, the epidemic is mainly concentrated in MSM, with little more than $50 \%$ of the total accumulated cases; but with an upward trend, in recent years, also in heterosexual cases. ${ }^{9}$ There are a series of guides and manuals on primary and secondary prevention, diagnosis and treatment of HIV/AIDS and Sexually Transmitted Infections (STIs) directed to health services staff ${ }^{10}$ within the framework of Official Mexican Standard NOM-010-SSA2-2010 for the prevention and control of HIV infection. But as in Colombia, despite having different guidelines, manuals and regulations, it is still a public health problem. ${ }^{11,12}$

\section{EPIDEMIOLOGICAL DATA}

In Colombia, according to data from the United Nations Program on HIV/AIDS (UNAIDS) in 2015, the number of people living with HIV/AIDS was 150,000 cases. In turn, estimates from the same organization found that the prevalence in persons between 15 and 49 years old was $0.5 \%, 140,000$ persons of at least 15 years old are living with HIV; and regarding the same age, it was reported that 40,000 women live with this diagnosis. ${ }^{11}$ According to data from the epidemiological surveillance system, 1,818 accumulated cases were notified at the epidemiological week 39 (September 24-30, 2017) Bogotá city. ${ }^{12}$

As already noted in Mexico from the beginning of the epidemic in 1983 until November 2016, according to the National Center for the Prevention and Control of HIV and AIDS (CENSIDA for its initials in Spanish) in 2016, 186,655 accumulated cases of people with AIDS have been reported. In turn, reported cases of HIV/AIDS that are alive according to the recorded evolution are: AIDS 72,599; HIV: 62,916 for a total of 135,515 . The most affected age group in both men and women is between 20 and 49 years of age, that is, of people in full reproductive and economically active age. Most of the transmission is sexual, according to the CENSIDA, 3,954 cases were reported for this category of transmission. ${ }^{13}$ 


\section{ACCESS TO THE HEALTH SYSTEMS OF COLOMBIA AND MEXICO}

First of all, universal access implies the maximum coverage of HIV prevention, treatment, care and support services for those who need them. Among the basic principles for universal access, services must be equitable, accessible, affordable, comprehensive and sustainable in the long term. Because each scenario usually has different needs, each country set its own objectives for universal access. For them it is required that these services have adapted strategies of HIV prevention, an appropriate clinical attention, nutritional and psychological support, support to the activities of daily and social life, the involvement of people living with HIV and their families, and respect for human rights and legal needs. But it must take into account the social determinants of health, these being the circumstances in which people are born, grow, live, work and age, including the health system. These circumstances are the result of money, power and resources distribution at global, national and local levels, which in turn depend on the adopted policies. ${ }^{14}$

Access to health care in Colombia is due to the health system based on the General System of Social Security in Health (SGSSS) created in the year of 1993 (Law 100). ${ }^{15}$ It is a health system of regulated competition, a mixture of public and private service and marketregulation, whose main sources of financing are the contributions of employees and employers, which finance the contributory regime and the fiscal resources obtained through general taxes, that fund the subsidized regime. In the area of public health, the SGSSS includes collective actions addressed to population and environment groups, grouped in the Collective Action Plan (PAC). On the other hand, there is a set of actions in charge of the Service Provider Institutions (IPS) who are responsible for providing services to users, according to social benefits while Health Promoting Companies (EPS) are public and private entities that operate as insurers and administrators; which since 2003, are guided by standards and guides for early detection and specific protection of national scope. It is necessary to mention that public health is mainly the responsibility of the municipalities and departments and, as it happens with the subsidized regime, these territorial entities use their own resources. ${ }^{15}$

According to data from the High Cost Account which is a Colombian Fund for High Cost Diseases like HIV, as of January 31, 2015, people living with HIV are more representative in the contributory system with 35,477 cases, and in the subsidized regime there are $24,615 .^{16}$ People living with HIV, depending on the department and regime, are mostly concentrated in areas where there is a greater urban population, Bogotá serves $81.87 \%$ of all cases in the contributory system, followed by San Andrés with $70.67 \%$ and Antioquia $66.64 \% .^{16}$

While access to health care in Mexico is given by the health care system which includes two sectors: public and private. Within the public sector are: The Mexican Institute of Social Security (IMSS) with a mandatory regime, which protects the majority of its members, and a voluntary regime. ${ }^{17}$ The mandatory regime comprises five basic branches of social protection: sickness and maternity insurance, occupational risk insurance, disability and life insurance, retirement and old-age insurance, social benefits, day-care insurance and others. The affiliates of the Institute of Security and Social Services for State Workers (ISSSTE), who are employees of the government, pensioners, retirees and their families, have a set of benefits similar to those offered by the IMSS, their health insurance guarantees the access to preventive medicine, maternity, medical, surgical, hospital, pharmaceutical, and physical and mental rehabilitation services. ${ }^{17}$

The insured workers of Mexican Petroleum (PEMEX), the Ministry of Defense (SEDENA) and the Ministry of Navy (SEMAR) have medical, surgical and hospital care for the first, second and third levels; pharmaceutical and rehabilitation coverage; work risks, retirement and disability insurance. The health services provided by social security institutions to their members are financed by contributions from the employer (which in the case of ISSSTE, PEMEX and Armed Forces is the government), worker or employee and government contributions. ${ }^{17}$ 
The institutions and programs of the public sector that serve the population who do not have social security are a General Health Insurance called "Seguro Popular" (SPS), which guarantees access to a package with around 260 health interventions, with their respective medications, that members receive in the State Health Services (SESA) units. ${ }^{17}$ It also offers a package of 18 high-cost interventions, including treatment for child cancer, cervical cancer, breast cancer, HIV/AIDS and cataracts. The population with no insurance receives, in the units of the SESA, basic ambulatory services in rural health centers and a more or less broad set of interventions in large cities. ${ }^{17}$ Finally, the IMSSOpportunities Program (IMSS-O) offers services mainly in rural areas through first-level clinics and second-level rural hospitals. The attention is focused on general ambulatory medicine services and maternal and child hospital services. The private sector includes insurance companies and service providers that work in clinics, clinics and private hospitals, including providers of alternative medicine services. ${ }^{17}$

\section{CONCEPT OF QUALITY ATTENTION IN COLOMBIA AND MEXICO}

The Ministry of Health of Colombia takes the quality and humanization of the care as a way to respond to the needs of people and contribute to the purpose of the SGSSS, managing to start life in the best conditions, stay healthy in family, live in a healthy community informed of their rights and duties regarding health, timely detect the disease and recover health, living with the disease or functional diversity with autonomy and respect and face death with dignity. ${ }^{18}$

In Mexico, the concept of quality includes attention, as well as the sphere of action in the areas of prevention, detection, comprehensive care and surveillance; all of them consider interculturality, sexual diversity, gender perspective, human rights and quality, as transversal axes in the provision of services, inclusive of and applicable to key population. Having comprehensive prevention strategies is a necessary but not sufficient condition to mitigate the damages caused by HIV and other STIs.
Health care quality is a crucial component to improve personal and public health care services and outcomes. ${ }^{19}$

\section{CARRIED OUT ACTIONS REGARDING THE ATTENTION TO PEOPLE WITH HIV/AIDS IN COLOMBIA}

A study conducted in 2011 on attitudes, susceptibility and self-efficacy against HIV/AIDS in health professionals where one of the instruments applied was the AIDS phobia scale to 34 health professionals belonging to a health entity in the city of Cali; in the AIDS phobia scale in relation to the forms of HIV transmission and nontransmission, it was observed that $17.6 \%$ of people would be frightened to care for a patient with AIDS, $20.6 \%$ would feel uncomfortable being in the same room with a person who had AIDS and $23.5 \%$ would not eat food that has been prepared by someone with HIV. ${ }^{20}$ Specifically, $17.6 \%$ of health professionals are not concerned about transmitting HIV to other people and $14.7 \%$ consider that they have a high risk of becoming infected with HIV, although health providers have knowledge about the HIV infection and a positive attitude towards diagnosed people, but it is necessary to work on strategies that change some behaviors such as negative attitudes and some fears related to having contact with people who have a HIV diagnosis. ${ }^{20}$

Also, in that same year (2011) a quantitative and qualitative descriptive study was conducted, addressed to children under 18 affected with HIV/AIDS and their caregivers, in health institutions belonging to the state and private sectors of five Colombian cities (Cali, Buenaventura, Barranquilla, Santa Marta and Cartagena). Two hundred and eighty-six people participed in the study, 11 were children who knew about their diagnosis of HIV seropositivity and 275 caregivers of children with diagnosis. Fifteen groups were formed with three different populations: children who knew about their diagnosis, caregivers that did not know about the child's diagnosis, health institutions officers who offer services to people with HIV/AIDS. The results regarding quality care in relation to the waiting time for the consultation for children and caregivers was higher than 30 minutes for 
$53.8 \%$ while $32.6 \%$ must wait between $15-30$ minutes and only $13.5 \%$ receive immediate attention. The majority of users $(70.6 \%)$ consider that health care is respectful and friendly, $29.1 \%$ consider that there is not good care and $0.3 \%$ believes that sometimes it is. However, the testimonies obtained in the groups, mainly in the city of Buenaventura, indicated the absence of guarantees of a respectful and friendly service that provides confidentiality. ${ }^{21}$

A cross-sectional study in 2015 aimed to describe the social stigma in the care of people with HIV/AIDS with a convenience sample of 1253 students and professionals from the health care areas of Medellin, enrolled or graduates from some of the six universities offering undergraduate programs in these areas in the city. In this study, the highest frequencies of stigma were: $57.2 \%$ of the respondents would provide differential treatment to people with HIV/AIDS; $52.5 \%$ consider necessary to create exclusive hospitals for this group; $49.7 \%$ think that the care of these patients increases the risk of infection and leaves the great concern that $43.3 \%$ see the need to isolate the seropositive persons. ${ }^{22}$ The main predictors of social stigma were the academic program, the performance of the presumptive test and the semester of study, this research concluded that social stigma was higher in the first training cycles and corroborates the need to improve communication strategies, health information and education to combat stigma. ${ }^{22}$

\section{CARRIED OUT ACTIONS REGARDING THE ATTENTION TO PEOPLE WITH HIV/AIDS IN MEXICO}

A qualitative study conducted in 2003, in the states of Guerrero, Morelos and the Federal District (today Mexico City) where 40 interviews were conducted to people living with HIV/AIDS, 20 of each sex and unrelated, who reported more than a year of diagnosis and ambulatory status. $^{23}$ The informants were recruited in HIV/AIDS selfhelp groups, infectious disease services of public hospitals. Interview guides were designed and tested where different aspects of the experience of living with HIV/AIDS were explored, including treatments, perception of the disease, life quality, physical and emotional health and the relationship with medical personnel. As a result, the trajectory of seeking care from people with HIV/AIDS goes through several phases: the desire and the search for attention and the continuation of care. These phases in turn are associated with different types of problems. For the interviewees, the desire for attention was delayed, and once a certain malaise was present, the attention searches were discontinuous and many of the responses coming from the health personnel were misguided. In the care continuation phase, the greatest problem found was poor adherence to treatments. ${ }^{23}$

A qualitative and quantitative study in nine institutions in 2006 sought to analyze the stigma and discrimination related to HIV/AIDS by health service providers in three states of the Mexican Republic, based on the perceptions they have about the infection and people living with HIV/AIDS (PLWHA). ${ }^{24}$ The study was realized through 14 in-depth interviews and 373 surveys to health service providers. As a result, $75 \%$ of the providers received training related to HIV/AIDS, in spite of which discrimination persists due to the classifications in risk groups; the identification of living with the virus, suffering from the syndrome and dying; and ignorance of the transmission routes. Twenty-three percent of people would not buy food from a PLWHA and $16 \%$ suggest to forbid their access to public services. Regarding confidentiality, $89 \%$ think that it should be protected. Isolation, HIV registration in records, mandatory tests and delay in surgical procedures of PLWHA were constant practices. $^{24}$

\section{CONCLUSIONS}

The quality of care in these users with a diagnosis of HIV/AIDS is still deficient in health services. In Colombia and Mexico, it is necessary to work on strategies that change negative attitudes and fears associated with having contact with people with HIV/AIDS. It is essential to guarantee a respectful and friendly service that provides confidentiality. It corroborates the need to improve communication, information and health 
education strategies to combat stigma and greater adherence to the treatment of this population.

\section{REFERENCES}

1. Programa conjunto de las Naciones Unidas sobre el VIH/SIDA (ONUSIDA). Informe mundial: informe de ONUSIDA sobre la epidemia mundial de SIDA 2012. Ginebra: ONUSIDA; 2012. TechnicalReport Series: ONUSIDA. JC2417S

2. Programa conjunto de las Naciones Unidas sobre el VIH/SIDA (ONUSIDA). Informe mundial: informe de ONUSIDA sobre la epidemia mundial de SIDA 2013. Ginebra: ONUSIDA; 2013. TechnicalReport Series: ONUSIDA/JC2502/1/S

3. Sudharshan S, Biswas J. Introduction and immunopathogenesis of acquired immune deficiency syndrome. Indian J. Ophthalmol. 2008;56(5):357-62

4. Araújo LF. El origen del sida después de tres décadas desde sus primeros diagnósticos. Psicología \& Sociedade2014;26(1):248-249.

5. Soler-Palacín P, Provens AC, Martin-Nalda A, Espiau M, FernandezPolo A, Figueras C. Indicadores de calidad asistencial para la atención de personas que viven con los virus de la inmunodeficiencia humana adaptados a la edad pediátrica. Enferm. Infecc. Microbiol. Clin. 2014;32(3):160-169.

6. Ministerio de Salud y protección social de Colombia (MINSALUD). Guía de práctica clínica basada en la evidencia científica para la atención de la infección por VIH/Sida en adolescentes con 13 años o más y adultos. Bogotá, Colombia: MINSALUD; 2014. [Access 2018 February 11]. Available from: http://gpc.minsalud.gov.co/gpc_sites/Repositorio/Otros_conv/GPC_ VIH_adolescentes/gpc_vih_adolescentes_completa.aspx

7. Pulido Álvarez A. Reseñas: Guías de promoción de la salud y prevención de enfermedades en la salud pública, Modelo de gestión programática y guía para el manejo del VIH/SIDA, Guía para el manejo y modelo de prevención y control de la enfermedad renal crónica. Rev. Gerenc. Polit. Salud 2007;6(13):169-173.

8. Arrivillaga-Quintero M. Análisis de las barreras para la adherencia terapéutica en mujeres colombianas con VIH/Sida: cuestión de derechos de salud. Salud Pública Méx. 2010;52(4):350-356.

9. Magis C, Parrini R. Nuestra Epidemia El SIDA en México 1983-2002. In: Magis C, Barrientos H, Editors. VIH/SIDA y Salud Pública Manual para personal de salud. México: Centro Nacional para la Prevención y el control del VIH/SIDA (CENSIDA); 2009. p. 37-46.

10. Centro Nacional para la Prevención y el control del VIH/SIDA (CENSIDA). Guía de prevención, diagnóstico y tratamiento de las ITS. México: FUNSALUD; 2011. [Access 2018 February 7]. Available from: https://www.gob.mx/censida/documentos/guia-deprevencion-diagnostico-y-tratamiento-de-las-its.

11. Programa conjunto de las Naciones Unidas sobre el VIH/SIDA (ONUSIDA). Estimaciones sobre el VIH y el sida 2016 [homepageonthe Internet]. Colombia: ONUSIDA; c2016 [updated 2017; cited 2018 February 13]. Available from: http://www.unaids.org/es/regionscountries/countries/colombia.

12. Instituto Nacional de Salud de Colombia. BoletínEpidemiológico 2017 [homepage on the Internet]. Colombia: MINSALUD; c2017 [updated 2018; cited 2018 February 13]. Available from:
http://www.ins.gov.co/buscador-eventos/Paginas/Vista-BoletinEpidemilogico.aspx.

13. Centro Nacional para la Prevención y el control del VIH/SIDA (CENSIDA). Resumen de la Vigilancia Epidemiológica del Registro Nacional de Casos SIDA al 15 de noviembre de 2016 [homepageonthe Internet]. México: CENSIDA; c2016 [updated 2016; cited 2018 February 8]. Available from: http://www.censida.salud.gob.mx/descargas/epidemiologia/RN_DIA MUNDIAL_2016a.pdf.

14. Programa conjunto de las Naciones Unidas sobre el VIH/SIDA (ONUSIDA). Orientaciones terminologícas [homepage on the Internet]. Ginebra: ONUSIDA; c2011. [updated 2011; cited 2018 February 15]. Available from: http://files.unaids.org/en/media/unaids/contentassets/documents/unai dspublication/2011/JC2118_terminology-guidelines_es.pdf.

15. Calderón CAA, Botero JC, Bolaños JO, Martínez RR. Sistema de salud en Colombia: 20 años de logros y problemas. Ciênc. Saúde Coletiva. 2011;16(6):2817-2828.

16. Fondo Colombiano de Enfermedades de alto costo (Cuenta de alto costo). Situación del VIH en Colombia 2015 [homepageonthe Internet]. Colombia: Cuenta de alto costo; c2015. [updated 2015; cited 2018 February 15]. Available from: https://cuentadealtocosto.org/site/images/Publicaciones/Situacio\%C C\%81n\%20de1\%20VIH\%20en\%20Colombia\%202015.pdf.

17. Gómez-Dantés O, Sesma S, Becerril VM, Knaul FM, Arreola H, Frenk J. The health system of Mexico. Salud Pública Méx. 2011;53 (Suppl. 2):220-232

18. Ministerio de Salud y protección social de Colombia (MINSALUD). Calidad y Humanización de la atención [homepageonthe Internet]. Colombia: MINSALUD; c2017. [updated 2017; cited 2018 February 16]. Available from: https://www.minsalud.gov.co/salud/publica/PI/Paginas/calidadhumanizacion-atencion.aspx

19. Secretaria de salud de México. Programa de acción Especifico Respuesta al VIH, SIDA e ITS 2013 - 2018 [homepageonthe Internet]. MEXICO: Secretaria de salud de Mexico; c2014. [updated 2014; cited 2018 February 16]. Available from: http://www.censida.salud.gob.mx/descargas/acerca/PAE_2013_2018 AUTORIZADA.pdf

20. Uribe AF, Orcasita LT. Evaluación de conocimientos, actitudes, susceptibilidad y auto eficacia frente al VIH/SIDA en profesionales de la salud. Av. Enferm. 2011;29(2):271-284.

21. Trejos Herrera AM, Tuesca Molina RJ, Mosquera Vásquez M. Niñez afectada con VIH/SIDA: Uso y acceso a servicios de salud en cinco ciudades colombianas. Salud Uninorte 2011;27(2):171-184.

22. Tamayo-Zuluaga B, Macías-Gil Y, Cabrera-Orrego R, Henao-Pelaéz $\mathrm{JN}$, Cardona-Arias JA. Estigma social en la atención de personas con VIH/Sida por estudiantes y profesionales de las áreas de la salud, Medellín, Colombia. Rev.Cienc. Salud.2015;13(1):9-23.

23. Herrera C, Campero L, Caballero M, Kendall T. Relación entre médicos y pacientes con VIH: Influencia de apego terapéutico y calidad de vida. Rev. Saúde Pública 2008;42(2):249-55

24. Infante C, Zarco A, Magali-Cuadra S, Morrison K, Caballero M, Bronfman M, et al. El estigma asociado al VIH/SIDA: el caso de los prestadores de servicios de salud en México. Salud Pública Mex.2006;48:141-150. 